\title{
Facilitating community development with housing microfinance: appraising housing solutions for Pakistan after disasters
}

\author{
F. Tariq \\ College of Design, North Carolina State University, USA
}

\begin{abstract}
After the deadly floods and earthquakes, more than two third Pakistanis were in urgent need of assistance. Malnutrition and homelessness are continuing threats to the victims of these disasters. The scope of destruction is so wide that instead of huge international donations and governmental efforts for relief and reconstruction, the situation is not healing effectively and the gap is enlarging day by day between supply and demand of houses. In early 2010, after these tragedies, Central Bank statistics revealed that now there is a total shortage of 8.8 million houses and 700,000 houses/year must be provided to cope with the increasing demand. Especially for low-income households, there is a dearth of financial resources to build/renovate damaged and destroyed houses; this is worsened by the fact that non-sustainable methods and materials that are used continue to be vulnerable in future disasters. There is an urgent need for policy change in Pakistan towards innovative housing strategies including financial and technical assistance programs.
\end{abstract}

Keywords: housing microfinance, incremental housing, pre-fabricated.

\section{Introduction}

Housing is a major place-based infrastructure element and an integral part of the community fabric. It has a profound impact on the social, economic, and physical character of a community. The 'basic needs' approach introduced by the International Labour Organization in 1976 included shelter along with food and clothing as a basic need [1]. But "the very complicated problem of satisfactorily housing people on a national scale has not been solved in most countries of the world" (Turner and Fichter [2]). The UN Centre for Housing Development 
(Habitat) estimates that one quarter to one third of urban residents of third world countries live in absolute poverty and contends that an active housing policy should be seen as a strategic economic and social investment that will generate large multiplier effects in backward and forward linkages and productivity [3].

Hardoy and Satterthwaite [4] examined housing policies of 17 third world countries and concluded that only two of them had incorporated programs for low-income families in their national housing policy. The same is the case with Pakistan where $24 \%$ of the total population (170 million) is living below the poverty line [5]. Government agencies in Pakistan have experimented with a wide range of low-income housing programs including sites and services, low cost core units and slum upgrades. However, government-produced housing covers a negligible part of need and demand. To implement their urban development and housing programs, government agencies turned to land acquisition, as the chosen instrument to obtain the land needed for current projects and to reserve for future use. Attempts by the government to restrain land speculation and to acquire private undeveloped urban land for low-income shelter at below-market prices were typically met with great resistance by private landowners. For instance, Punjab Housing and Town Planning Agency (PHATA) is facing an annual drop of 3000 housing units due to the fact that it had to acquire land at market price in pursuance of Land Acquisition Act (1985) and deliver them on non-profit basis. So, as a solution, most of the public agencies develop low-income housing societies in physically distant localities to avoid high land costs [6]. On the user end, these housing tracts cannot gain popularity because they are inconveniently far from the main city. This happens to most of government developed low-income housing projects. The public sector's failure to anticipate and respond to housing demand of low-income people continues to result in the creation of slums or irregular settlements known as katchi abadis all over the country. For example, in Karachi, which has a population over 10 million, more than half of its inhabitants are living in squatter or illegally developed informal settlements. Also, there has been no recent housing census since 1981 on which one can target precise solutions according to exact figures. For example, in Lahore, according to the Lahore Development Authority, there were 750,000 people living in squatter areas in the early $90 \mathrm{~s}$ without proper provision of civic amenities, but this is contradicted by much higher unofficial estimates [7].

Owning a decent house seems an unachievable dream for almost half of the population of Pakistan. The housing development sectors have failed to provide adequate housing for the poor. There is a need for innovative ways through which the poor can take control of their own housing needs through access to finance for the construction and improvement of their homes. In Pakistan commercial banks have been reluctant for a variety of reasons - including lack of faith in the trustworthiness of the poor and inadequate databases containing pertinent information on potential borrowers - to provide adequate credit for the poor to build housing for themselves and their families. 


\section{Housing microfinance}

Microfinance, which is a financial innovation generally considered to have originated with the Grameen Bank in Bangladesh, facilitates the provision of a wider range of financial services to the very poor. Microfinance is the extension of very small loans to those in poverty to spur entrepreneurship. The poor individuals who lack collateral, steady employment and a non verifiable credit history cannot meet the minimal qualifications to gain access to traditional credit. Microfinance has enabled extremely impoverished people to engage in self-employment projects. The United Nations declared 2005 'The International Year of Microfinance' [8].

This global movement is expanding day by day to provide small-scale loans, savings accounts, insurance and other broader financial services in poor and lowincome communities. They are indeed unlocking the productive potential of poor by growing small businesses [9]. It was estimated that at the end of 2007, there were 154.8 million people that are served by 3350 microfinance institutions all over the world [10]. On average microfinance institutions lend $\$ 120$ per loan with a maturity period up to one year, wherein commercial banks find no profit because of high transaction cost in such a small loan size with longer maturity periods [11]. Microfinance suits the poor people of third world countries because it sprang out of their culture and was developed specifically with their needs and strengths in mind.

Apart from providing loans for income generating activities and emergency situations [12], microfinance housing programs have also attained a prominent position in many countries. The Center for Urban Development Studies at the Harvard Design School undertook an assessment of current housing microfinance practices. The Center had developed six detailed case studies of leading microfinance programs: the Grameen Bank in Bangladesh, SEWA Bank in India, the Center for Agriculture and Rural Development and Payatas Scavengers Association in the Philippines, the South African Homeless People's Association, Genesis in Guatemala and highlighted the linkages between housing and microfinance, the challenges facing the extension of micro credit to poor households for shelter construction and improvements, land acquisition and infrastructure provision [13].

It is often perceived that housing loans are not income generating but "in reality housing is not only shelter but also a commodity that offers social security" (Smets [14]). It can also be an income generating source if a room is rented out or converted into a workplace. It has also been assumed that housing loans should be large and of longer term. But there are innovative housing finance schemes that opt for short to medium term loans [14] where people themselves do development when the resources become available to them.

In his book, Housing by People, Turner [15] said that when dwellers control the major decisions and are free to make their own contribution to the design, construction or management of housing, both the process and the environment produced stimulate individual and social well being. And where dwellers are in 
control, their homes are typically better and cheaper than those built through government programs or large corporations [16].

\section{Housing situation and microfinance in Pakistan}

Like other developing countries, poor people in Pakistan are exposed to housing shortages and low income. According to the housing census of 1980, the number of housing units was increased by $2.1 \%$ during a corresponding $3 \%$ increase in population. According to International Bank for Reconstruction and Development, the rate of residential plots development and provision of infrastructural facilities was also inadequate to keep up with demand. On the demand side, due to high inflation of building materials, the ability of poor people to find a way to construct a house has been lowered significantly [17]. In early 2010, it was estimated that there is a total shortage of 8.8 million houses [18] and that this gap will continue to grow because of new demand for 700,000 houses /year with the supply of only 300,000 houses /year [18].

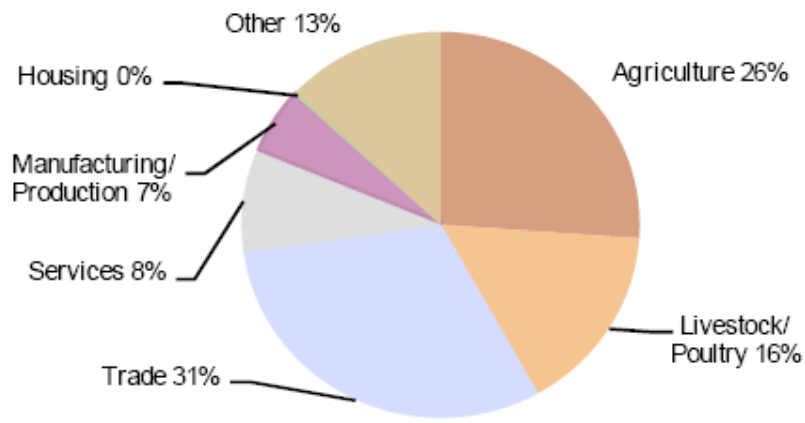

Figure 1: $\quad$ Microfinance services in different sectors.

According to the global report on human settlements 2005 "housing microfinance is an important potential resource for increasing the rate, scale and quality of housing supply" (UN Habitat [19]). Further it suggested that improvement or extension in existing units can generate more domestic space which can be rented out or for home-based enterprise. The lessons of the Grameen Bank have been replicated worldwide. Yet, despite the close proximity and historical ties between Bangladesh (the symbolic home of microfinance innovation) and Pakistan, housing microfinance remains very limited in Pakistan. Table 1 provides results from a survey attempting to explain barriers to borrowing for housing in Pakistan [20].

If we look at the pie chart below; we see that most of microfinance services in Pakistan are targeted to the agricultural and livestock sectors [21].

So microfinance and in particular housing microfinance is not so popular in Pakistan. 
Table 1: $\quad$ Reasons for not participating in Microfinance.

\begin{tabular}{|c|c|c|c|c|c|c|}
\hline $\begin{array}{c}\begin{array}{c}\text { Most } \\
\text { obvious }\end{array} \\
\text { reason in } \\
\text { Pakistan } \\
\text { not } \\
\text { borrowing } \\
\text { large loans } \\
\text { (Rs. 1000 } \\
\text { or above) } \\
\text { Category }\end{array}$ & $\begin{array}{c}\text { No } \\
\text { reason to } \\
\text { borrow }\end{array}$ & $\begin{array}{c}\text { Do not } \\
\text { like } \\
\text { asking } \\
\text { for } \\
\text { loans }\end{array}$ & $\begin{array}{c}\text { Complicated } \\
\text { and } \\
\text { lengthy } \\
\text { procedure }\end{array}$ & $\begin{array}{c}\text { On } \\
\text { religious } \\
\text { grounds }\end{array}$ & $\begin{array}{c}\text { No } \\
\text { collateral } \\
\text { available }\end{array}$ & $\begin{array}{l}\text { Other } \\
\text { reason }\end{array}$ \\
\hline $\begin{array}{c}\text { All } \\
\text { Pakistan }\end{array}$ & $59 \%$ & $17 \%$ & $8 \%$ & $2 \%$ & $10 \%$ & $4 \%$ \\
\hline \multicolumn{7}{|c|}{ GENDER } \\
\hline Male & 63 & 13 & 13 & 3 & 7 & 3 \\
\hline Female & 57 & 20 & 4 & 1 & 12 & 5 \\
\hline
\end{tabular}

\section{Incremental housing}

There are many studies which reveal that poor people build and improve houses incrementally as needs arise due to increases in family or as means become available. "In developing countries, $70 \%$ of housing investment occurs progressively - that is, households acquire land through purchase or invasion, and gradually improve the structure and legal tenure, and lobby for basic services. A useful approach for housing in this context offers a wider range of low-cost solutions rather than just complete new units" (Ferguson and Navarrete [22]). "For individuals or households with limited incomes, the only possibility of home ownership (even in the illegal settlement) is through shelter investment made in several stages. Land purchase, service installation and upgrading, as well as housing construction, consolidation and expansion, all are made at separate times" (UN Habitat [23]). This process may take years to complete a unit. As "incremental building demand incremental financing" (Abrams [24]), so housing microfinance seems to be a good match.

According to Smets [25], a microloan with maturity period of 5 years or less can enable flexibility, as labor and materials are added incrementally for construction or improvement over a period of years. "Loan finance enables occupiers to 'bring forward' the higher standards to the 'present time' of building; the loan repayment scheme allows households to adjust and smooth their patterns of consumption, saving and investment" (Pugh [26]). "It helps to 
make borrowing more affordable; it reduces interest charges and encourages rapid repayment to qualify for further loans" (Baumann and Bolnick [27]).

The Incremental Building approach accounts for 50 to $90 \%$ of residential development in most developing-country cities [28]. The global report on human settlements-2005 has also emphasized the fact that "finance is the most important dimension of securing sustainable solutions that can fill the gap between the two extreme outcomes of current systems and processes: affordable shelter that is inadequate and, adequate shelter that is unaffordable" (UN Habitat [29]).

\section{Design issues}

Because not designed from the start, incremental construction, whether it is the addition of a room or improvement of an existing structure, often involves destruction. There is a lot of waste of building materials, labor and all other resources. "However should shelter be constructed in the most efficient way"? Smets [30]. Yes and with some design guidance, the incremental construction of housing could be done with much less waste. The lack of involvement of technical advice on incremental construction results in low quality and therefore creates great environmental and land use problems. Mohni Malhotra in her article 'Financing her home, one wall at a time' had given example of Grameen housing loan products which required borrowers to meet minimum health and safety standards [31]. As argued by Tilock [in 32, p. 115], incremental housing activities should have the technical assistance for at least three major reasons: 1. risk management; to ensure overall structural integrity, such that a new roof is able to support a second storey or will not be lifted off during a hurricane. 2. Institutional reputation and client satisfaction: this methodology is adopted by CHF International and FUNHAVI in Mexico, it improved living conditions and encourage clients' neighbors to also borrow loans and 3. organizational mission: to provide affordable housing with quality.

There is a necessity of providing cost effective technical assistance to poor clients that is tailored to their needs [33]. The role of the architect becomes obvious here in order to made modular designs for incremental housing units. There is a practice in Quinta Monroy, Chile, where architectural group 'ELEMENTAL' designed incremental homes. With the help of the government, it has been decided to design full houses with a half home constructed first. All the units have been designed to have access to public space and adequate ventilation. The units are also structurally sound to withstand the earthquakes that affect the area occasionally. The overall arrangement took the 100 families that were living on the land, and redistributed them into 4 smaller communities, each arranged around a common public space. The units were basically designed as duplexes and initial space of each unit was about 30 square meters, which could be expanded up to 72 square meters. 

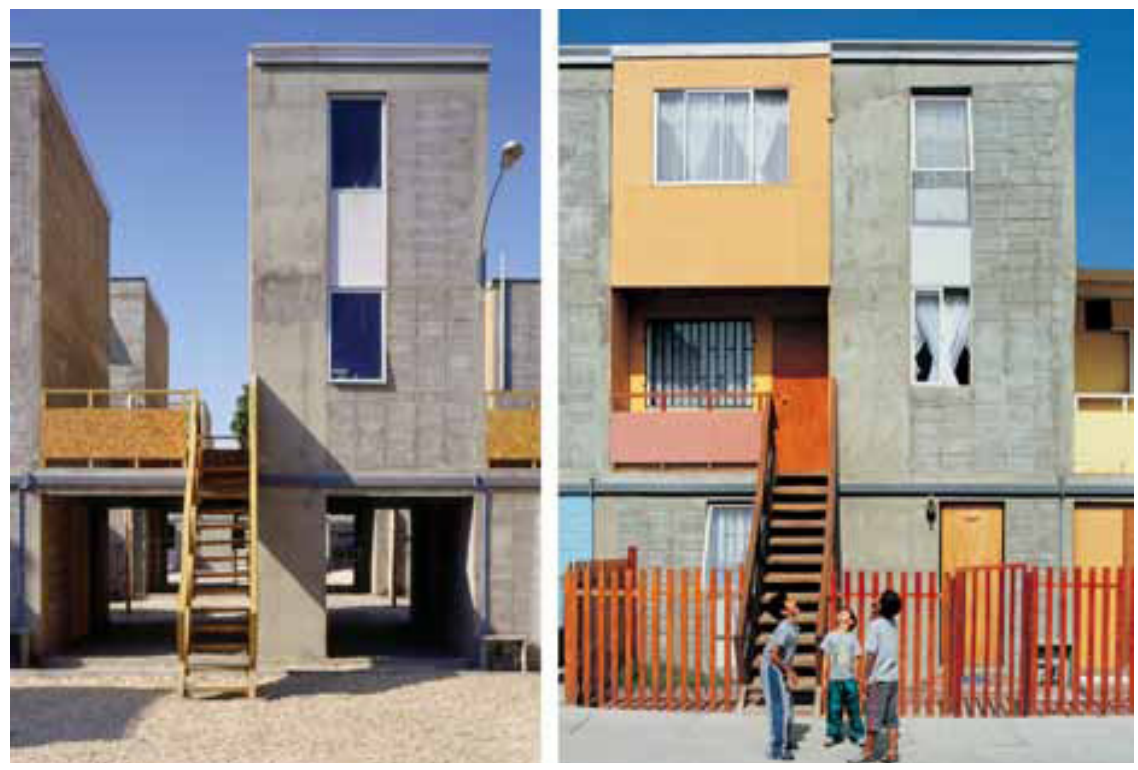

Figure 2: $\quad 36 \mathrm{~m}^{2}$ initial $+36 \mathrm{~m}^{2}$ self built units in Quinta Monroy, Chile.

\section{Housing in Pakistan after disasters}

After the July 2010 floods in Pakistan, the largest private sector land developers in Pakistan had promised to construct 10,000 housing units in flood-affected areas. The government of Punjab and armed forces have also initiated smallscale model housing projects in affected areas with the help of local NGOs and international donations from countries including the US, China and Turkey. Also, the NGO Habitat for Humanity had provided some dome-shaped transitional shelters using galvanized sheet metal roofing in disaster struck communities [34]. But the scope of destruction is so wide that instead of huge international donations and governmental efforts for relief and reconstruction, the situation is not healing effectively and the gap is enlarging day by day between supply and demand of houses.

Commonly, "much of the housing of the poor is vulnerable to serious damage from natural disasters. Housing on steep hillsides and in flood plains may be destroyed by heavy storms and the flimsy materials available to poor are likely to withstand earth quakes, high winds or fire" (Bartlett et al. [35]). Houses in Pakistan typically have walls made of baked or unbaked bricks, with roofs made of reinforced cement concrete or iron girders. Fifty one percent of the houses in squatter settlements are concrete. The difference is seen in the standard of houses and the level of services available which depend on income of household living there [36].

A modular house designed with pre-fabricated material is becoming popular in Pakistan. A pre-fabricated house can be built in extended versions with time 
as the family grows or as more resources become available. The design that relates to the traditions of local people with capacity of 7 people (the average household size in Pakistan is 6.8 [37]) may be a solution in opportunity for disaster struck areas. The pre-designed house plan (Figure 3) includes three bedrooms, a kitchen, two washrooms, workshop and a social area. The units had a two-storey plan with bathrooms and the kitchen placed on same wall to optimize services installations. To ensure privacy, the windows are placed at the opposite side of the entrance door. This not only facilitates cross ventilation in the room but also brings a better visual impression when entering the space, making it also look bigger. The pre-fabricated units are lighter compared with masonry constructions so this reduces construction cost of foundations.


Figure 3: $\quad 34 \mathrm{~m}^{2}$ ground floor plan with additional 2 rooms on the second floor to be added as and when need arises.

\section{Role of building material suppliers}

There is a 2007 study, which reveals that in São Paulo, families financed about a third of their purchases mainly using consumer credit. The construction material stores reported that their sources of financing typically qualified customers for a maximum of US $\$ 1500$ in credit which covers the average cost for the building materials to add one room [38]. The burden on low-income families can be reduced by allowing materials to be drawn on credit through local commercial suppliers. Recent experience in Mexico and elsewhere has shown that there is a great potential to expand housing microfinance along with using the credit culture operated by household goods retailers [39].

\section{Conclusion}

It appears that there is a natural complementarity between incremental construction and microfinance. The need of the time is to integrate this process with efficient, safe and aesthetically acceptable architectural house designs. For 
these pre-designed houses the costs involved in material and labor can be financed by micro loans and credit facilities offered by building material suppliers. In this way poor people can build incrementally designed, safe homes. Particular to Pakistan, there should be adequate campaigns to advertise acceptance of pre-fabricated systems in the construction market and the construction companies must provide earthquake-resistant standards and technical controls.

\section{References}

[1] Denton, J. A., Society and the Official World: A Reintroduction to Sociology: General Hall Dix Hills, New York, pp. 14-17, 1990.

[2] Turner, J. \& Fichter, R., Freedom to build: dweller control of the housing process (Chapter 8). User and Community involvement in housing and its effect on professionalism: The Macmillan Company, New York, pp. 176, 1972.

[3] Jacobsen, K., et al., Building A Foundation; Poverty, Development, and Housing in Pakistan. Harvard International Review, 23(4), pp. 20-25, 2002.

[4] Hardoy, J. E. \& Satterthwaite, D., Squatter citizen: life in the urban third world: Earthscan Publications Ltd, pp. 85-90, 1989.

[5] Akhtar, S., Building Inclusive Financial System in Pakistan, Financial Inclusion Conference; London, United Kingdom, pp. 2-10, 2007.

[6] Tariq, F. \& Butt, A. Q., Alternative Approach: The Case of Low- income Housing, Science International (Lahore), 20 (1), pp. 67-69, 2008.

[7] Alvi, I., The informal sector in urban economy: low income housing in Lahore: Oxford University Press, Karachi, pp. 50-58, 1997.

[8] Definition of Micro finance Online. http://en.wikipedia.org/wiki /Micro_finance

[9] Armendáriz, B. \& Morduch, J., The economics of microfinance (Chapter 1). Rethinking Banking: The MIT Press, pp-1-29, 2010.

[10] Daley-Harris, S., State of the microcredit summit campaign report 2009, Microcredit Summit Campaign: Washington, DC, pp. 4-76, 2009.

[11] Armendáriz, B. \& Morduch, J., The economics of microfinance (Chapter1). Rethinking Banking: The MIT Press, pp-1-29, 2010.

[12] Smets, P., Small is beautiful, but big is often the practice: Housing microfinance in discussion: Habitat International, 30(3), pp. 595-613, 2006.

[13] Building Assets, Building Credit: A Symposium on Improving Financial Services in Low-Income Communities Online.http://www.jchs.harvard.edu /babc/index.html

[14] Smets, P., Small is beautiful, but big is often the practice: Housing microfinance in discussion: Habitat International, 30(3), pp. 595-613, 2006.

[15] Turner, J., Housing by people-Towards autonomy in building environments. (Chapter 2). Pollution of Resources: Pantheon books, New York, pp. 33, 1976. 
[16] Turner, J. \& Fichter, R., Freedom to build: dweller control of the housing process (Chapter 8). User and Community involvement in housing and its effect on professionalism: The Macmillan Company, New York, pp. 177, 1972.

[17] Ghaus, A. \& Pasha, H. A., Magnitude of the housing shortage in Pakistan, The Pakistan Development Review, 29, pp. 137-153, 1990.

[18] Dawn news Online. http://www.dailytimes.com.pk/default.asp? page $=2010$ 102\03\story_3-2-2010_pg5_8

[19] UN Habitat, Financing urban shelter: global report on human settlements 2005, Earthscan and UN Habitat, London, 2005.

[20] Chino, T., Report and recommendation of the President to the Board of Directors on proposed loans to the Islamic Republic of Pakistan for the microfinance sector development program, Asian Development Bank, 2000.

[21] Muhammad, S. D., Microfinance Challenges and Opportunities in Pakistan, European Journal of Social Sciences, 14(1), p. 88, 2010.

[22] Ferguson, B., and Navarrete, J., New approaches to progressive housing in Latin America: A key to habitat programs and policy, Habitat International, 27, pp. 309-323, 2003.

[23] UN Habitat, Financing urban shelter: global report on human settlements 2005, Earthscan and UN Habitat, London, 2005.

[24] Abrams, C., Man's struggle for shelter in an urbanizing world, The MIT Press Classics Series, 1966.

[25] Smets, P., Small is beautiful, but big is often the practice: Housing microfinance in discussion: Habitat International, 30(3), pp. 595-613, 2006.

[26] Pugh, C., The idea of enablement in housing sector development: The political economy of housing for developing countries, Cities, 11(6), pp. 357-371, 1994.

[27] Baumann, T. \& Bolnick, J., Out of the frying pan into the fire: the limits of loan finance in a capital subsidy context, Environment and Urbanization, 13(2), p. 103, 2001.

[28] Ferguson, B., \& Smets, P., Finance for incremental housing; current status and prospects for expansion, Habitat International, 34(3), pp. 288-298, 2010.

[29] UN Habitat, Financing urban shelter: global report on human settlements 2005, Earthscan and UN Habitat, London, 2005.

[30] Smets, P., Small is beautiful, but big is often the practice: Housing microfinance in discussion: Habitat International, 30(3), pp. 595-613, 2006.

[31] Malhotra, M., Financing her home, one wall at a time, Environment and Urbanization, 15(2), pp. 217-229, 2003.

[32] Daphnis, F. \& Ferguson, B. (eds). Housing microfinance: a guide to practice, Kumarian Press: Bloomfield CT, 2004.

[33] Malhotra, M., Financing her home, one wall at a time, Environment and Urbanization, 15(2), pp. 217-229, 2003. 
[34] Habitat for Humanity Pakistan Online. http://www.habitat.org/intl/ap /154.aspx?tgs=My80LzIwMTEgMzo 1NDoyNyBQTQ\%3d\%3d

[35] Bartlett, S., Hart, R., Satterthwaite, D., de la Barra, X., \& Missair, A., Cities for Children: Children's right, Poverty and Urban Management: Earthscan Publications Ltd: London, pp. 45, 1999.

[36] Alvi, I., The informal sector in urban economy: low income housing in Lahore: Oxford University Press, Karachi, 1997.

[37] Population Census Organization-1998 Online. http://www.census.gov.pk /Statistics.htm

[38] Ferguson, B., \& Smets, P., Finance for incremental housing; current status and prospects for expansion, Habitat International, 34(3), pp. 288-298, 2010.

[39] UN Habitat, Financing urban shelter: global report on human settlements 2005, Earthscan and UN Habitat, London, 2005. 